\title{
Medical Interns and COVID-19: results of national research
}

\author{
(iD) Maria M. C. Carrascosa ${ }^{1}$ \\ (iD) Tercio de Campos 2 \\ (iD) Jéssica E. Sampaio ${ }^{1}$ \\ (iD) Rafaella R. F. Souza ${ }^{1}$ \\ (iD) Vitória L. Ribeiro ${ }^{1}$ \\ (iD) Maria L. N. Maia ${ }^{1}$ \\ (DD)Laura C. L. Gama ${ }^{1}$ \\ (iD) Mariana P. Severino ${ }^{1}$ \\ (D) Nathan K. Semer ${ }^{1}$ \\ (D) Otávio Rondon ${ }^{1}$ \\ (iD) Juliana B. M. Silva' \\ (iD) Mariana Miyazi \\ iD Samara R. Domingues' \\ (D) Nathália E. S. Batalha \\ (iD) Delio E. Martins ${ }^{3}$
}

1. Aluno do curso de medicina do $9^{\circ}$ semestre da Universidade Anhembi Morumbi, São Paulo, SP, Brasil 2. Professor do curso de medicina da Universidade Anhembi Morumbi, São Paulo, SP, Brasil 3. Coordenador do curso de medicina da Universidade Anhembi Morumbi, São Paulo, SP, Brasil

http://dx.doi.org/10.1590/1806-9282.66.6.812

\section{SUMMARY}

OBJECTIVE: Assess the impact of COVID-19 on medical students' internships in public and private institutions in Brasil, in addition to estimating the quality of the measures taken by their respective Universities in the face of the problem and the availability of personal protective equipment (PPE).

METHODS: A descriptive cross-sectional quantitative analysis study carried out with 317 students undergoing medical internship from March 31, 2020, to April 12, 2020. The survey was conducted through an online questionnaire using the SurveyMonkey tool with 20 questions. Interns from the fourth to the sixth year of medical schools in the country were randomly included in the study through a survey sent by Whatsapp application. Statistical analysis was performed using the Chi-Square, considering $p<0.05$ as significant.

RESULTS: Four main topics were identified in the research: student demographic data; how classes and courses are being taught; the use and ease of access to personal protective equipment and the students' fears and perspectives for the future.

CONCLUSION: The study clarified that although half of the students still have some degree of content and, in their majority, they are satisfied, there is still a lot of difficulty in obtaining personal protective equipment, which prevents students from returning safely to their internships.

KEYWORDS: Coronavirus Infections. Personal protective equipment. Internship and Residency. 


\section{INTRODUCTION}

In December 2019, in the Hubei province, in Wuhan, China, there was an outbreak of SARS, which would later be discovered as a new virus in circulation, Covid-19 $9^{1-3}$. The virus can cause pneumonia, fever, cough, fatigue, or have an asymptomatic presentation. With an incubation period of 3 to 14 days before the onset of symptoms, it went unnoticed, which could explain its worldwide prevalence ${ }^{1-3}$.

The WHO recommends that the personal protective equipment (PPE) indicated for health workers who come into contact with many people, many of whom presenting no symptoms, include gloves, goggles or face shield, cap, surgical mask, special masks (N95 or FFP2) and apron ${ }^{3}$. However, from the beginning of the Covid-19 pandemic in Brasil and worldwide, there have been reports of PPE shortage in hospitals, and in many cases, their absence brings concerns about the safety of medical students in hospital environments. The use of PPE is already scarce in this environment, so many were removed from their internship facilities ${ }^{4.5}$.

The Covid-19 pandemic changed routines throughout the world with the need for social distancing, quarantines, remote classes, the use of new tools, the aid of digital technology, and work from home. However, medical interns, who are important in hospital environments, find themselves in an intermediary situation, between the regular program, in which remote classes are possible, and the in-person care of patients, which has been modified and carried out by doctors to optimize the use of PPE, of which there is a shortage ${ }^{6}$.

Thus, the goal of this study is to evaluate the situation of medical interns in the current Covid-19 pandemic scenario.

\section{METHODS}

This study is a cross-sectional quantitative analysis, of descriptive nature, and was approved by the Medical Ethics Committee under number 3,979,279.

The survey was conducted based on an online questionnaire using the SurveyMonkey tool and comprising 20 questions divided into the following subjects: demography; how the program has been carried out so far; use and ease in acquiring PPE; and students' fears and perspectives.

The survey was sent to medical students from the 4th to the 6th year of the program from all over the country, randomly, via WhatsApp application.

This research was carried out between 31 March
2020 and 12 April 2020. The statistical analysis was performed using the chi-square test, considering $\mathrm{p}<0.05$ as statistically significant. The presentation of the measured variables is shown by graphs.

\section{RESULTS}

A total of 317 students agreed to participate in the research. Figure 1 shows the states from which the answers come.

Most of the respondents study in private institutions (77.9\%). From the total number of respondents, $54.5 \%$ are 5 th-year students, $44.2 \%$ 6th-year, and 1.3\% 4th-year.

On the contents of the internship, $50.2 \%$ (159) have their content completely halted; $42.6 \%(135)$ have their contents partially halted, with theoretical content being offered remotely; and $7.2 \%$ (23) provided different answers. There was no difference between students from public and private institutions $(\mathrm{p}=0.0783)$.

Most students with halted internships required adaptations, and many universities began to offer remote classes. Figure 2 shows how the contents are being offered.

On PPE, 71.6\% (227) reported difficulty of access. Of the $44.5 \%$ (141) students who have access to PPE, 70 are provided by the hospital or internship facility, 54 have protective equipment provided by the university, and 17 have acquired it themselves. There was no difference between students from public and private institutions.

Figure 3 shows how the training related to PPE was carried out, demonstrating that students from public

FIGURE 1. STATES WHERE STUDENTS STUDY.

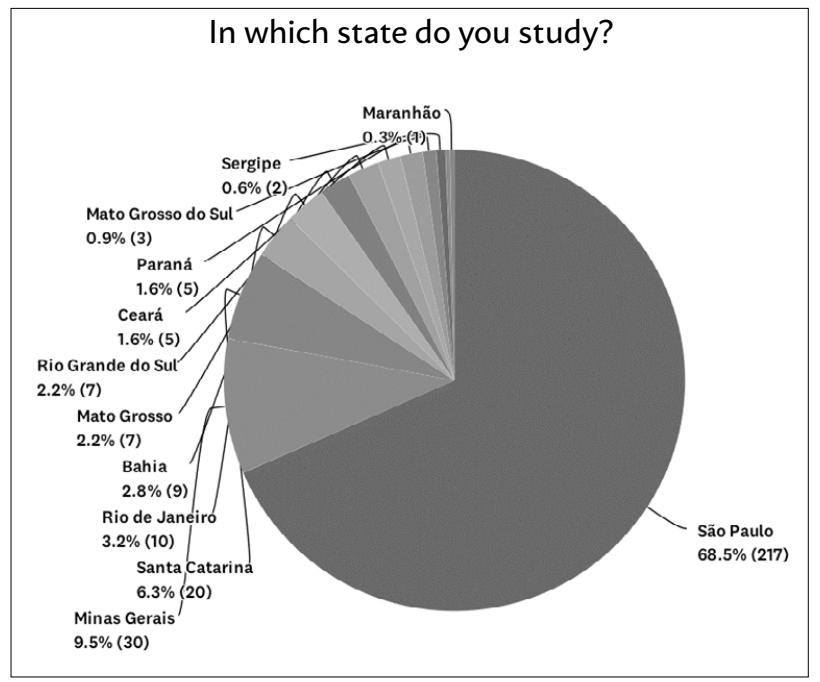


FIGURE 2. DYNAMIC OF ACTIVITIES AND QUALITY OF REMOTE CLASSES DURING THE COVID-19 PANDEMIC, COMPARING SCHOOLS PUBLIC AND PRIVATE INSTITUTIONS $(P=1,000)$

Dynamic of activities and quality of remote classes

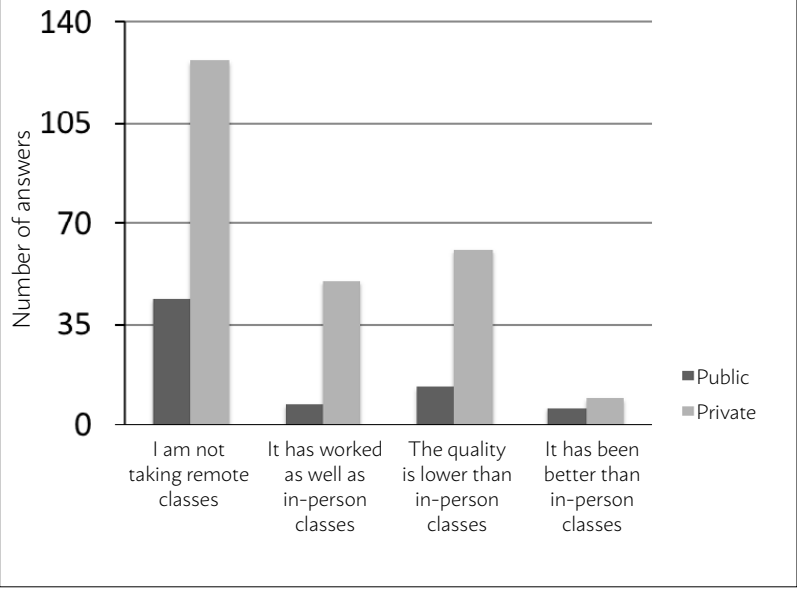

FIGURE 3. TRAINING ON THE USE OF PPE, COMPARING STUDENTS FROM PUBLIC AND PRIVATE INSTITUTIONS $(P=0.0015)$

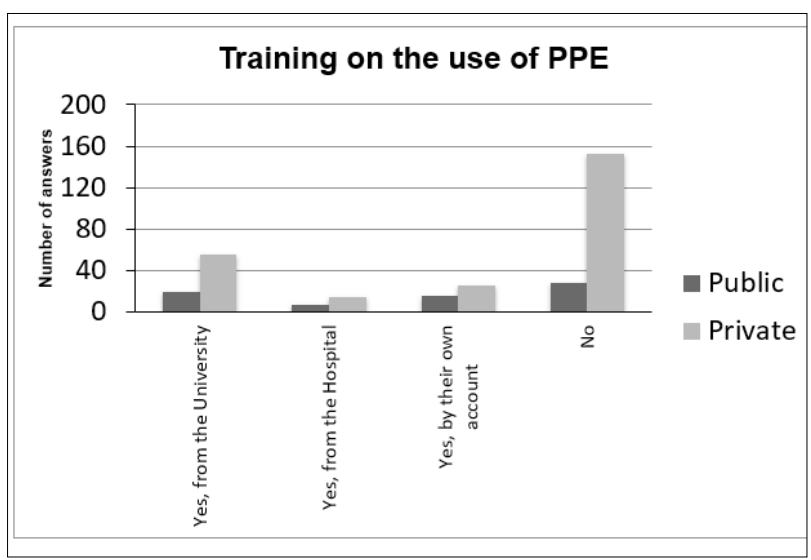

institutions received more training. With respect to the theoretical content on Covid-19 and guidance to students, $41.6 \%$ (132) received this content, but $58.4 \%$ (185) did not receive any content or guidance. When comparing the types of institutions, there was a difference between those who received training $(58.6 \%$ public $x 36.8 \%$ private, $\mathrm{p}=0.0015$ ).

Regarding the safety to see patients, $44.2 \%$ (140) of the respondents do not feel safe to care for patients in the emergency room, 39.7\% (126) consider themselves partially safe, $10.7 \%$ (34) consider themselves safe, and $5.4 \%$ (17) consider other safety issues regarding the care of patients in the emergency room in the current pandemic. There was no difference between students from public and private institutions.

With respect to the fear of contamination by the virus, $80.8 \%$ (256) of the interns are afraid of being contaminated and 19.2\% (61) did not have this fear.

If the respondents had the option, 34.7\% (110) would prefer to work as volunteers wherever there was a need, $30.6 \%$ (97) would stay at home until the pandemic was over, $29.7 \%$ (94) would like to have continued with their regular internship, and 5.0\% (16) would prefer to perform other activities. There was no difference between students from public and private institutions ( $\mathrm{p}=$ n.s.)

With regard to their perspectives, 50.0\% (158) feel insecure, because they do not know how they will compensate the lost internship time; $21.5 \%$ (68) are worried because this situation will delay their graduation; $19.9 \%$ (63) are calm, trying to seize the opportunity for medical learning; and 8.5\% (27) have other expectations.

When asked about their degree of satisfaction with how the University is handling the situation, 36.0\% (114) said they are dissatisfied, 25.2\% (80) are satisfied, $20.2 \%(64)$ are very dissatisfied, $14.2 \%$ (45) are indifferent, and only $4.4 \%$ (14) are satisfied with their Universities in this new scenario. There was no difference between students from public and private institutions.

\section{DISCUSSION}

The Coronavirus Resource Center, of the Johns Hopkins University, revealed that by 30 April 2020, the current Covid-19 pandemic had already affected more than 3 million people worldwide, of which more than 80 thousand are in Brasil, and had caused the death of over 230,000 people worldwide?

This has transformed everyday life throughout the world. One of the first establishments to interrupt activities were schools because they are not considered essential activities. In addition, with the current technological advances, it is possible to offer remote classes in order to maintain the continuity of programs. However, medical students undergoing internships find themselves in an intermediary situation. The internship is the stage in which students begin their in-hospital activities, with some kind of theoretical content as a foundation. And, to exercise their in-hospital activities, PPE is required so they can be adequately protected. In the current pandemic, there is a general lack of protective equipment, leaving medical interns, who do not yet have the autonomy to perform medical practices, as the last ones to have access to PPE. Thus, they may be the class of students who are the most affected by the 
current situation, causing them a series of problems and anxiety.

Considering students who are taking remote classes, half of them reported that the classes have equal or superior quality to the traditional in-person classes. Some institutions have trained their teachers, further enhancing these indexes. For example, the Anhembi Morumbi University provided training for $100 \%$ of its teachers regarding the new type of media used for the classes and the handling of the remote tool; as a result, 23 of the 35 internship students (65.6\%) who are taking remote classes considered them to be of equal or better quality than in-person classes.

An important issue to be considered is that $71.6 \%$ of the respondents reported difficulties in getting PPE. Due to this difficulty, universities, hospitals, and students themselves have been making efforts to purchase PPE. This overall difficulty prevents students from safely resuming their internships. Another relevant aspect is the training of students on the disease and the use of PPE. Many reports describe health professionals who were contaminated while putting on or taking off their PPE. Over half of the students reported receiving no theoretical content on Covid-19 (58.4\%), nor any training on the use of PPE (57.1\%). When comparing students from public and private institutions, we notice that more students from public institutions received specific training than those from private institutions [58.6\% vs. 36.8\%, $\mathrm{p}=0.0015$ and $60 \%$ vs. $38.1 \%, \mathrm{p}=0.0015$, respectively analyzed regarding theoretical content and training on the use of PPE].

Another relevant aspect is that only $10.7 \%$ of the respondents considered themselves safe to care for patients in the emergency room during the pandemic, while $80.8 \%$ reported being afraid of being contaminated with the virus, which demonstrates widespread insecurity regarding the current situation. This problem is reported by Lai et al., who showed the psychological effects among 1,257 health professionals who worked in Wuhan during the peak of the pandemic and identified high rates of depression (50.4\%), anxiety (44.6\%), insomnia (34\%), and stress (71.5\%) among those interviewed ${ }^{8}$.

All of these aspects are directed to educational institutions, who must provide swift answers to situations never before experienced or seen. Of all the respondents, $56.2 \%$ reported some degree of dissatisfaction with the way their educational institution is handling the current situation. This was expected because, in a moment such as this, virtually everyone had some loss. All sectors of society have varying degrees of dissatisfaction. According to research conducted by the Instituto Datafolha ${ }^{9}$, for $69 \%$ of the population, the pandemic will decrease their income, generating negative prospects for society. It is up to the educational institution to support students at this moment when many of them are isolated from their families, without being able to go to their internships or return home.

We believe that, in universities in general, some points of attention could improve the level of satisfaction of these students, such as streamlining the communication channel between the coordination staff and students and providing psychological support to students. In addition to communication, another key point regards information and knowledge. Thus, there should be investments in technical communication about the disease and the use of PPE and also in general communication that is not specific to this problem. New communication channels should be opened for students, and there should be investments in the individualization of specific problems.

In addition, investments in PPE can be useful for returning to usual activities. Such return can happen in two ways: the situation reaches a point of balance and internships are resumed, or the number of serious cases increases greatly and the role of students as volunteers will have greater relevance. This voluntary work can count as at least part of the students' internship since they will be experiencing a unique moment in medicine that has not happened in the last hundred years; this makes it easier to compensate for lost internship time. These aspects can improve the understanding of students, reduce fears and concerns, and increase the value of educational institutions for students and their families.

This study has some limitations: despite having national coverage it could not equally contemplate all educational institutions. Still, the number of respondents from each of the educational institutions is limited. In addition, the proportion of answers has no statistical calculations to support them.

On the other hand, this is the first study carried out in the country that exposes the situation of medical interns in the Covid-19 pandemic and can serve as a basis for actions planned by the institutions, assisting them in handling medical internships during this period. 


\section{CONCLUSION}

It can be concluded, based on this study, that remote education is a viable and suitable alternative for part of the medical internship support content and should be used extensively to train all interns on the Covid-19 pandemic and the use of PPE. In addition, the creation of new communication channels during this moment of a pandemic can increase the safety of students and improve their perception of educational institutions and their role in this crisis that involves the entire health system of Brasil and the rest of the world.

\section{Acknowledgments}

Special thanks to Isabelle Munhoz, Rodolfo S. J. Lázzaro, Maira Mari, Mariana S. Vasconcelos, and Isadora R. Mendes for their support of the project, and to all the students who, somehow, contributed for this work to be possible, from contributions to the dissemination of the questionnaire to the interns, who dedicated a little of their time to answer it.

\section{Contribution of the authors}

Maria M. C. Carrascosa: Organized and divided the project and its activities. Prepared the questionnaire and helped in its rapid dissemination for the recruitment of subjects for data collection. Wrote the introduction and results. Found and selected references from 1 to 5 , which were used in the preparation of the article. Was responsible for the first version of references 1 to 5 . Was responsible for the first revision of the article in Portuguese. Translated the title, introduction, results, and images of the article into English, and formatted the work in English and revised it. Formatted and prepared the article according to the requirements of the journal.

Tércio de Campos: Had the idea for the project. Coordinated the project. Wrote the discussion and conclusion. Contributed to improvements in the introduction, methods, and results of the project. Selected references 6 to 9 used in the article. Revised the work. Submitted the work to the Brasil platform and to the Research Ethics Committee.

Jessica E. Sampaio: Assisted in the rapid dissemination of the questionnaire for the recruitment of subjects for data collection. Participated in the drafting of the project objectives and title. Standardized the references according to the Vancouver style. Formatted the project in Portuguese.

Rafaella R. F. Souza: Assisted in the rapid dissemination of the questionnaire for the recruitment of subjects for data collection. Participated in the drafting of the presentation text of the questionnaire and the questionnaire itself. Participated in the drafting of the project objectives and title. Drafted the abstract for the project.

Vitória L. Ribeiro: Assisted in the rapid dissemination of the questionnaire for the recruitment of subjects for data collection. Revised the methodology in Portuguese and translated it into English. Organized the initial bibliography $(3,4,5)$.

Maria L. N. Maia: Assisted in the rapid dissemination of the questionnaire for the recruitment of subjects for data collection. Participated in the drafting of the introduction and in the translation of the discussion.

Laura C. L. Gama: Assisted in the rapid dissemination of the questionnaire for the recruitment of subjects for data collection. Contributed to the drafting of the questionnaire text, helping to draw up the method.

Mariana P. Severino: Assisted in the rapid dissemination of the questionnaire for the recruitment of subjects for data collection. Drafted the methodology. Translated the abstract into English.

Nathan K. Semer: Assisted in the rapid dissemination of the questionnaire for the recruitment of subjects for data collection. Drafted the abstract and translated it into English.

Otávio Rondon: Assisted in the rapid dissemination of the questionnaire for the recruitment of subjects for data collection. Translated the introduction and results.

Juliana B. M. Silva: Assisted in the rapid dissemination of the questionnaire for the recruitment of subjects for data collection. Translated the discussion into English.

Mariana Miyazi: Assisted in the rapid dissemination of the questionnaire for the recruitment of subjects for data collection. Participated in the drafting of the questionnaire.

Samara R. Domingues: Assisted in the rapid dissemination of the questionnaire for the recruitment of subjects for data collection. Drafted the title and objectives.

Nathália E. S. Batalha: Assisted in the rapid dissemination of the questionnaire for the recruitment of subjects for data collection. Translated the methodology.

Délio E. Martins: Conducted a critical review of the project and manuscript, contributing to the discussion. 


\section{RESUMO}

OBJETIVO: Avaliar o impacto da Covid-19 durante o internato dos alunos de medicina em escolas públicas e particulares no Brasil, além de estimar a qualidade das medidas tomadas pelas respectivas universidades diante do agravo e da disponibilização de equipamento de proteção individual.

MÉTODO: Um estudo de análise quantitativa transversal, com caráter descritivo, foi realizado com 317 alunos cursando o internato médico durante o período de 31 de março de 2020 a 12 de abril de 2020. A pesquisa foi realizada por meio de um questionário on-line com 20 perguntas pela ferramenta SurveyMonkey. Os internos do $4^{\circ}$ ao $6^{\circ}$ ano das faculdades de medicina do País foram incluídos no estudo de forma randômica ao receberem a pesquisa pelo aplicativo WhatsApp. A análise estatística foi realizada por meio do Qui-quadrado, considerando $p<0,05$ como significante.

RESULTADOS: Quatro temas principais foram identificados na pesquisa: dados demográficos dos alunos; como as aulas e estágios do curso estão sendo ministrados; a utilização e facilidade de aquisição do equipamento de proteção individual e medos e perspectivas futuras dos estudantes.

CONCLUSÕES: O estudo mostrou que apesar de metade dos alunos continuarem tendo algum grau de conteúdo e, na maioria, estarem satisfeitos, ainda há muita dificuldade em se obter equipamento de proteção individual, o que impede que os alunos retornem com segurança aos seus campos de estágio, além de causar medo de contaminação e de continuar atendendo os pacientes.

PALAVRAS-CHAVE: Infecções por coronavírus. Equipamento de proteção individual. Internato e residência.

\section{REFERENCES}

1. Velavan TP, Meyer CG. The COVID-19 epidemic. Trop Med Int Health. 2020;25(3):278-80.

2. World Health Organization. WHO Statement regarding cluster of pneumonia cases in Wuhan, China. Geneva: World Health Organization; 2020 [cited 2020 Apr 8]. Available from: https://www.who.int/china/news/ detail/09-01-2020-who-statement-regarding-cluster-of-pneumoniacases-in-wuhan-china

3. World Health Organization. Rational use of personal protective equipment for coronavirus disease (COVID-19): interim guidance. Geneva: World Health Organization; 2020. [cited 2020 Apr 8]. Available from: https:// apps.who.int/iris/handle/10665/331215

4. Newman M. Covid-19: doctors' leaders warn that staff could quit and may die over lack of protective equipment. BJM. 2020;368:m1257.

5. Amaral M, Maciel A, Dip A, Domenici T, Dolce J, Pina R, et al. Escassez no SUS: profissionais da saúde relatam batalha contra coronavírus: médicos e enfermeiros enfrentam a Covid-19 no corpo a corpo e reivindicam testes, equipamentos de proteção e informação [Internet]. EXAME: 2020 Mar 28. [cited 2020 Apr 8]. Available from: https://exame.abril.com.br/brasil/escassez-no-sus-profissionais-da-saude-relatam-batalha-contra-coronavirus/

6. Grayson MS, Klein M, Lugo J, Visintainer P. Benefits and costs to community-based physicians teaching primary care to medical students. J Gen Intern Med. 1998;13(7):485-8.

7. Johns Hopkins University of Medicine. New cases of COVID-19 in world countries [Internet]. Johns Hopkins Coronavirus Resource Center; 2020 April. [revised 2020 Apr 20; cited 2020 Apr 20]. Available from: https:// coronavirus.jhu.edu/data/new-cases

8. Lai I, Ma S, Wang Y, Cai Z, Hu J, Wei N, et al. Factors associated with mental health outcomes among health care workers exposed to coronavirus disease 2019. JAMA Netw Open. 2020;3(3):e203976.

9. Instituto DATAFOLHA. Opinião sobre a pandemia coronavírus. Avaliação econômica. Brasil. DATAFOLHA; April, 2020. [DATAFOLHA Instituto de pesquisas] 